\title{
Jaguar and Puma Predation on Cattle Calves in Northeastern Sonora, Mexico
}

\author{
Octavio C. Rosas-Rosas, ${ }^{1}$ Louis C. Bender, ${ }^{2}$ and Raul Valdez ${ }^{3}$
}

Authors are ${ }^{1}$ Research Wildlife Biologist, Colegio de Postgraduados, Campus San Luis Potosi, Iturbide No. 73, Salinas de Hidalgo, San Luis Potosí, Mexico C.P. 78600; ${ }^{2}$ Research Wildlife Biologist, United States Geological Survey, New Mexico Cooperative Fish and Wildife Research Unit and Departments of Fishery and Wildlife Sciences and Animal and Range Sciences, New Mexico State University, PO Box 30003, MSC 4901, Las Cruces, NM 88003-0003, USA; and ${ }^{3}$ Department Head and Professor, Department of Fishery and Wildlife Sciences, PO Box 30003, MSC 4901, Las Cruces, NM 88003-0003, USA.

\begin{abstract}
Predation by jaguars (Panthera onca) and pumas (Puma concolor) is often a source of conflict with cattle ranching in northeastern Sonora, Mexico. Because jaguars are endangered in Mexico, such conflicts have biological, social, and economic consequences. We documented the extent of predation by jaguars and pumas on cattle in 1999-2004 in northeastern Sonora, where the northernmost breeding population of jaguars exists in North America. Jaguars and pumas killed only calves $<12$ mo old, and calves constituted $58 \%$ of prey biomass consumed by jaguars and $9 \%$ by pumas. Annual cause-specific mortality rates of confirmed jaguar predation $(\leq 0.018)$, confirmed and suspected jaguar predation $(\leq 0.018)$, and all confirmed and suspected large felid predation $(\leq 0.018)$ were low and cattle calf survival was high $(0.89-0.98$ annually). If calves reported as missing but for which no evidence of mortality could be found were classed as large felid predation, annual cause-specific rates increased to 0.006-0.038. Collectively, confirmed jaguar and puma predation accounted for $<14 \%$ (57/408) of total cattle losses, with jaguars responsible for $14 \%$ of all calf losses; this could increase to a maximum of $36 \%$ (146/408) if missing calves were included in the totals. While jaguar and puma predation may have an impact on some small cattle operations, it is generally minor compared to losses from other causes in northeastern Sonora. Moreover, $91 \%$ of all confirmed calf kills were associated with three individual jaguars in our study. Targeting problem cats rather than broad-scale predator control may therefore be a viable alternative to address chronic predation problems. Because most ( $83 \%$ ) instances of jaguar predation occurred during the dry season along thick riparian habitats, modified cattle husbandry operations, such as establishment of permanent water sources in uplands and away from dense vegetative cover, could ameliorate many cases of predation by jaguars on cattle.
\end{abstract}

\section{Resumen}

La predación por jaguares y pumas es a menudo fuente de conflicto con ganaderos en el Noreste de Sonora, México. Debido a que los jaguares están en peligro de extinción en México tales conflictos tienen repercusiones biológicas, sociales y económicas. Documentamos el grado de depredación en ganado por jaguares y pumas de 1999 al 2004 en el noroeste de Sonora, donde existe la población reproductiva de jaguares localizada más al norte en la región de Norte América. Los jaguares y pumas matan becerros de menos de 12 meses de edad, y los becerros constituyen el $57 \%$ de la biomasa de las presas consumidas por jaguares y $9 \%$ por pumas. La mortalidad anual por causas especificas debida a la depredación confirmada $(\leq 0.018)$, por los jaguares y la asumida $(\leq 0.018)$, y así como toda la confirmada y asumida de los felinos $(\leq 0.018)$, fue baja y la sobrevivencia de los becerros fue alta (0.89-0.98 anualmente). Si los becerros se reportaban como perdidos pero no se encontró evidencia de la mortalidad se clasificaron como depredación anual de de los felinos, así, la tasa de la causa específica anual se incrementó de 0.006-0.038. Colectivamente, (como grupo) la predación confirmada por jaguares y pumas contó $<14 \%$ (57/408) de la pérdida total de ganado, con los jaguares responsables del $14 \%$ de todas la pérdidas de los becerros; esto se podría incrementar a una máximo de $36 \%$ (146/408) si los becerros perdidos se incluyeran en los totales. Aunque la predación de jaguares y pumas quizá tengan un impacto en algunas operaciones ganaderas pequeñas, esta pérdida es generalmente menor comparada con pérdidas debidas a diferentes causas en el noroeste de Sonora. Además, $91 \%$ de las muertes confirmadas de becerros se asociaron con tres jaguares en nuestro estudio. El enfocarse en los felinos problemáticos, en lugar de llevar a cabo un control general de predadores podría ser una alternativa viable para manejar los problemas crónicos de la predación. Debido a que en la mayoría (83\%) de las instancias la predación de los jaguares ocurrió durante la época de sequía cerca de las zonas rivereñas, la modificación del manejo del ganado, tal como el establecimiento de fuentes permanentes de agua en zonas alejadas de las zonas rivereñas y de la densa vegetación, podría disminuir la predación del jaguar hacia el ganado.

Key Words: cattle, diet, jaguars, Mexico, mortality, predation, pumas, Sonora

\section{INTRODUCTION}

Correspondence: Louis C. Bender, New Mexico Cooperative Fish and Wild life Research Unit, New Mexico State University, PO Box 30003, MSC 4901, Las Cruces, NM 88003-0003, USA. Email: Ibender@nmsu.edu

Manuscript received 3 March 2008; manuscript accepted 9 July 2008.
Jaguars (Panthera onca) and pumas (Puma concolor) can be serious predators of livestock (Rabinowitz 1986; Hoogesteijn et al. 1993; Polisar et al. 2003; Cascelli de Azevedo and Murray 2007), and predation by these species is frequently a source of conflict for cattle ranchers in Sonora, Mexico. Jaguars are 
endangered and protected in Mexico (Secretary of Natural Resources of Mexico [SEMARNAT] 2002), and the northernmost population of jaguars in the Americas inhabits the Sierra Madre Occidental in northeastern Sonora, sympatric with pumas in a landscape primarily used for grazing cattle. Illegal killing because of livestock predation is probably the main threat to this population; from a minimum annual population of $\leq 8$ jaguars, at least 11 jaguars were illegally killed in this area from 1999 to 2005 (Martínez-Mendoza 2000; Rosas-Rosas 2006).

Cattle ranching is the main rural land use in northeastern Sonora and has a long cultural heritage (Martínez-Caraza 1983). In 2004, 300,000 cattle were sold for a total of approximately $\$ 110,000,000$ (Moreno-Martínez 2004). The inherited tradition of cattle ranching is strong in northeastern Sonora, and ranchers continue in livestock enterprises despite droughts, fluctuating beef markets, and predators. For many cattle operations, especially smaller ones, jaguar or puma predation on livestock can be a severe economic problem. Consequently, predators such as pumas or jaguars are frequently killed for merely being a potential threat to livestock in Sonora (Rosas-Rosas et al. 2003).

Past research suggests that jaguar and puma predation on livestock occurs because of learned behavior of specific individuals, injuries to jaguars, lack of appropriate cattle management strategies, lack of natural prey, local habitat attributes, weather, and human tolerance, including local culture and government policies (Hoogesteijn et al. 1993; Crawshaw and Quigley 2002; Polisar et al. 2003; Cascelli de Azevedo and Murray 2007). Understanding circumstances and impacts of jaguar and puma predation on livestock and preventing or mitigating predation is crucial for conserving large predators and their habitats (Patterson et al. 2004) and preserving economically viable cattle operations. Consequently, our goal was to determine the impacts of predation by jaguar and puma on cattle in northeastern Sonora. Specific objectives included to determine 1) survival rates of annual calf crops, 2) causes of mortality and cause-specific mortality rates for calves, and 3) the relative importance of cattle to the diet of jaguars and pumas in northeastern Sonora.

\section{METHODS}

\section{Study Area}

Our study area encompassed approximately $400 \mathrm{~km}^{2}$ in northeastern Sonora in the northern Sierra Madre Occidental (Fig. 1) and was located about $60 \mathrm{~km}$ southwest of Nácori Chico, a municipality approximately $270 \mathrm{~km}$ south of the Mexico-United States border. Topography in the study site was rocky and rugged with several intermittent and perennial streams. Elevations ranged from 500 to $1500 \mathrm{~m}$. Precipitation ranged from about $400 \mathrm{~mm}$ annually in the valleys to $1000 \mathrm{~mm}$ in higher elevations (Marshall 1957). There were two main seasons in the study site: the dry season (NovemberJune) and the wet season (July-October). Monsoonal rains characterize the wet season, and scattered rains are also present in winter (January-February). The main vegetation community was semitropical thornscrub (Brown 1982).

Minimum known populations of jaguars ranged from four to eight during our study, 1999-2005. We were less certain of

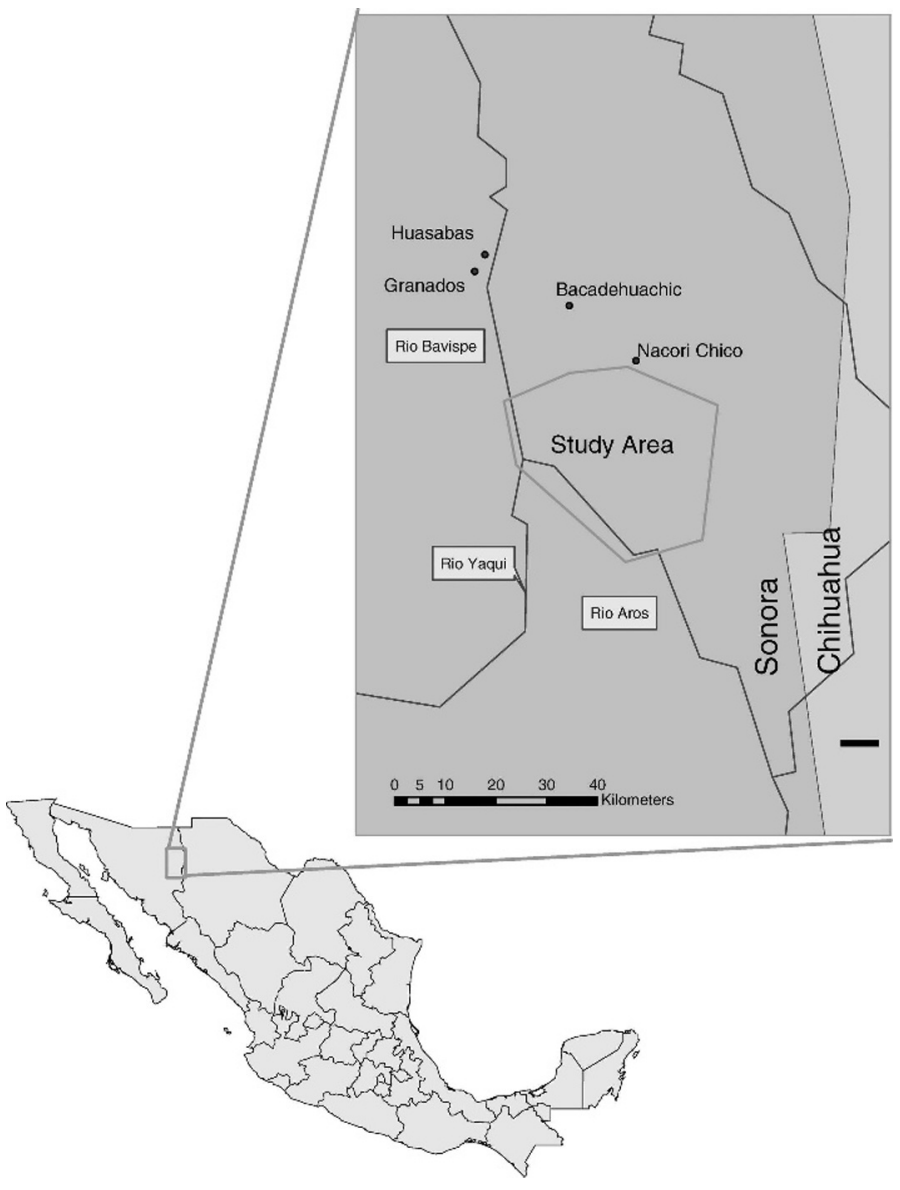

Figure 1. Location of study area in northeastern Sonora, Mexico, about $270 \mathrm{~km}$ south of the United States-Mexico border.

puma populations during this period, but a minimum estimate was $>14$ (Rosas-Rosas 2006). Other terrestrial prey mammals present included white-tailed deer (Odocoileus virginianus), jackrabbits (Lepus spp.), cottontail rabbit (Sylvilagus audubonii), coatimundi (Nasua narica), collared peccary (Pecari tajacu), opossum (Didelphis spp.), and rock squirrel (Spermophilus variegatus). Other potential predators of cattle included coyotes (Canis latrans) and bobcats (Lynx rufus).

Eleven cattle ranches made up the majority of our study area, and the total number of cattle within the study site over the period 1999-2004 averaged 2815 ( $\mathrm{SE}=226)$ including cows, bulls, steers, and calves (Table 1). Four ranches under single ownership totaled about 11,000 ha and held the most cattle within the study site (approximately $1200 \mathrm{cattle} \cdot \mathrm{yr}^{-1}$ ). The remaining ranches had 120-600 cattle each. Ranches were primarily managed for calf production, and calves were sold at about $6 \mathrm{mo}$ of age. Cattle management practices were dependent on rainfall. Cattle were rotated from upland pastures to areas with perennial water sources during the dry season, usually adjacent to perennial riparian areas. During the wet season all cattle freely ranged over upland pastures. One pasture in each ranch was always left as a reserve for severe droughts or harsh seasons. Calving was typically concentrated from March through July, although some $(<10 \%)$ calves were born throughout the year. 
Table 1. Total numbers of cattle present by age class, total number of losses claimed by ranches, and numbers of calves marketed on the 11 ranches making up our northeastern Sonora, Mexico, study area, 1999-2004.

\begin{tabular}{|c|c|c|c|c|c|c|c|}
\hline & 1999 & 2000 & 2001 & 2002 & 2003 & 2004 & Total \\
\hline Total cattle & 2034 & 2000 & 2509 & 2459 & 2944 & 2556 & 14502 \\
\hline Cows & 1570 & 1500 & 1829 & 1490 & 1879 & 1621 & 9889 \\
\hline Calves & 1200 & 1000 & 944 & 919 & 1113 & 960 & 6136 \\
\hline Claimed losses & 30 & 20 & 105 & 78 & 124 & 51 & 408 \\
\hline Calves sold & 1170 & 980 & 839 & 841 & 989 & 909 & 5728 \\
\hline
\end{tabular}

\section{Livestock Predation}

We used ranch records and field surveys to assess production, survival, and causes of mortality of cattle calves, June 1999December 2004. Information obtained from each ranch within the study site included 1) total number of cattle by sex and age classes (i.e., calf, yearling, and adult), 2) numbers of calves produced each year, as determined from observations of parturition and records of owners immediately following parturition, 3) number of cattle losses claimed each year, 4) suspected causes of death of cattle, 5) whether calves lost were branded, 6) number of pastures, 7) number of water sources available, and 8) number of calves sold per year. We compared data from field surveys to the number of claimed losses and causes of mortality for each ranch.

We conducted field surveys to locate calf mortalities throughout all calving areas in the study site and during track, scat, and camera-trapping surveys conducted throughout our study area (Rosas-Rosas 2006). We walked all trails, washes, roads, and other paths in areas where cattle were located daily during the main calving period, and approximately weekly throughout the remainder of the year, each year of the study. We also had ranch workers looking for dead calves, and they notified us when mortalities were found so that we could investigate and confirm cause of death. This approach allowed us to cover all general areas being used by cattle and allowed detection of mortalities up to approximately $5 \mathrm{~km}$ from the nearest cattle presence at time of detection of the mortality. Prompt location of dead calves was crucial to determining the actual cause of death because scavengers quickly located carcasses and modified conditions around the carcass. We usually detected kills by observing black vultures (Coragyps atratus) flying or perching around a particular site, noting carcass odors, following coyote tracks, or notification by ranch workers, which generally allowed rapid location of dead calves. We were able to locate $82 \%$ of jaguar and puma kills the day following the kill, $10 \%$ after $2 \mathrm{~d}$, and the rest $(8 \%)$ after $3 \mathrm{~d}$.

We classed mortalities as jaguar predation, puma predation, abandonment of the calf by the mother following birth, abnormal parturition (the calf dying during or immediately after birth), malnutrition (cow did not nurse the calf sufficiently or did not have enough milk), predators other than jaguar or puma, disease, and unknown. Unknown losses included calves that were reported missing by ranchers but for which we could find no evidence of mortality (unknown-missing) and calves for which we could not conclusively determine cause of death but were able to exclude predation (unknown-nonpredation). We necropsied all dead calves to determine if the animal died before it was fed on by carnivores, that is, whether it was predated or simply scavenged (see below). We emphasized determining true proximate causes of mortality and predator species because ranch workers and landowners invariably attributed livestock losses to predation without determining the actual cause of death.

We recorded clinical signs associated with each carcass as well as the characteristics of the immediate area. We recorded date, age of cow, predator sign (tracks and scrapes), body parts consumed, habitat attributes at kill site, whether the kill was covered with debris or not, approximate time since death, presence of scavenging, general health of the prey, position of bite marks, presence and location of canine punctures, distance between canine punctures, and any other general observations. We emphasized size and location of canine punctures and parts of each calf consumed to separate jaguar and puma kills. Jaguars normally kill their prey with a bite to the braincase or cervical vertebrae, although they occasionally also kill prey with a bite to the throat (Hoogesteijn 2001; Crawshaw and Quigley 2002). In contrast, pumas normally kill prey with a suffocating bite to the throat. Pumas also partially cover their prey with debris, rocks, and dirt to hide it from scavengers (Hoogesteijn et al. 2002), whereas jaguars do not (Hoogesteijn 2001; Crawshaw and Quigley 2002). Canine punctures from either felid cause hemorrhaging and consequent dark discoloration in the skin and bones; if puncture marks and associated hemorrhage were not present, it was unlikely that the animal was alive when fed on by a jaguar or puma, or killed by a large felid. Additionally, large felids usually first break the rib cage or chest to access internal organs such as the heart and lungs (Kitchener 1991). Following this, felids frequently start consuming their prey from the hindquarters. If neither of the above signs were present, it was unlikely that the calf was killed by a jaguar or puma. We identified other predator kills following O'Gara (1978).

We estimated annual survival rates of calves using the Kaplan-Meyer estimator (Pollock et al. 1989), which allowed for staggered entry of calves into survival models throughout the calving season. We used the method of Heisey and Fuller (1985) to estimate cause-specific mortality rates; for the latter, we made time periods (months) a uniform $30 \mathrm{~d}$ and attributed all mortalities to the midpoint of the month. For both survival models, the individual was the experimental unit, and survival or mortality rates were estimated monthly based on numbers of individuals (Kaplan-Meier) or individual days (Heisey-Fuller) at risk. We compared overall annual survival rates across years, and cause-specific mortality rates within years, using $Z$-tests (Pollock et al. 1989). For these comparisons we kept a constant experiment-wise error of $\alpha=0.05$ and determined pairwise 
Table 2. Annual cause-specific mortality rates $(M)$ and associated standard error (SE) of cattle calves in northeastern Sonora, Mexico, 1999-2004. Also shown are pooled annual rates for confirmed and suspected jaguar predation (Jaguar CS), all confirmed and suspected large felid predation (Felid CS), and all confirmed and suspected large felid predation plus calves that were reported missing but for which no evidence of mortality could be found (i.e., unknown-missing; Felid CSM). Comparisons of causes of mortality within years are limited to unique causes of mortality only (i.e., excludes pooled rates).

\begin{tabular}{|c|c|c|c|c|c|c|c|c|c|c|c|c|}
\hline \multirow[b]{2}{*}{ Cause } & \multicolumn{2}{|c|}{1999} & \multicolumn{2}{|c|}{2000} & \multicolumn{2}{|c|}{2001} & \multicolumn{2}{|c|}{2002} & \multicolumn{2}{|c|}{2003} & \multicolumn{2}{|c|}{2004} \\
\hline & $M^{1}$ & SE & $M^{1}$ & SE & $M^{1}$ & SE & $M^{1}$ & SE & $M^{1}$ & SE & $M^{1}$ & SE \\
\hline Jaguar & $0.018 \mathrm{a}$ & 0.0005 & $0.000 \mathrm{~b}$ & 0.0 & $0.008 \mathrm{~cd}$ & 0.0003 & $0.013 \mathrm{~b}$ & 0.0004 & 0.004 de & 0.0001 & $0.000 \mathrm{e}$ & 0.0 \\
\hline Puma & $0.000 \mathrm{~b}$ & 0.0 & $0.000 \mathrm{~b}$ & 0.0 & $0.002 \mathrm{e}$ & 0.0001 & $0.002 d$ & 0.0001 & $0.003 \mathrm{e}$ & 0.0001 & $0.005 \mathrm{c}$ & 0.0002 \\
\hline Abandonment & $0.002 \mathrm{~b}$ & $<0.0001$ & $0.000 \mathrm{~b}$ & 0.0 & $0.011 \mathrm{c}$ & 0.0004 & $0.009 \mathrm{c}$ & 0.0003 & $0.011 \mathrm{c}$ & 0.0003 & $0.000 \mathrm{e}$ & 0.0 \\
\hline Abnormal parturition & $0.002 \mathrm{~b}$ & $<0.0001$ & $0.003 \mathrm{~b}$ & 0.0001 & $0.006 \mathrm{~d}$ & 0.0002 & $0.007 \mathrm{c}$ & 0.0002 & $0.007 d$ & 0.0002 & $0.004 \mathrm{~cd}$ & 0.0001 \\
\hline Disease & $0.002 \mathrm{~b}$ & $<0.0001$ & $0.003 \mathrm{~b}$ & 0.0001 & $0.005 \mathrm{de}$ & 0.0002 & $0.003 d$ & 0.0001 & 0.004 de & 0.0001 & $0.001 \mathrm{de}$ & $<0.0001$ \\
\hline Other predator & $0.001 \mathrm{~b}$ & $<0.0001$ & $0.002 \mathrm{~b}$ & 0.0001 & $0.011 \mathrm{c}$ & 0.0004 & $0.002 d$ & 0.0001 & $0.003 \mathrm{e}$ & 0.0001 & $0.001 \mathrm{de}$ & $<0.0001$ \\
\hline Suspected jaguar predation & $0.000 \mathrm{~b}$ & 0.0 & $0.002 \mathrm{~b}$ & 0.0001 & $0.000 \mathrm{e}$ & 0.0 & $0.002 d$ & 0.0001 & 0.004 de & 0.0001 & $0.000 \mathrm{e}$ & 0.0 \\
\hline Unknown-missing & $0.000 \mathrm{~b}$ & 0.0 & $0.004 a b$ & 0.0001 & $0.019 \mathrm{~b}$ & 0.0006 & $0.012 \mathrm{~b}$ & 0.0004 & $0.027 \mathrm{~b}$ & 0.0008 & $0.018 \mathrm{~b}$ & 0.0006 \\
\hline Unknown-nonpredation & $0.002 \mathrm{~b}$ & $<0.0001$ & $0.006 \mathrm{a}$ & 0.0002 & $0.049 \mathrm{a}$ & 0.0016 & $0.033 \mathrm{a}$ & 0.0011 & $0.046 \mathrm{a}$ & 0.0014 & $0.024 \mathrm{a}$ & 0.0008 \\
\hline Jaguar CS & 0.018 & 0.0005 & 0.002 & 0.0001 & 0.008 & 0.0003 & 0.015 & 0.0005 & 0.008 & 0.0002 & 0.000 & 0.0 \\
\hline Felid CS & 0.018 & 0.0005 & 0.002 & 0.0001 & 0.010 & 0.0003 & 0.017 & 0.0006 & 0.011 & 0.0003 & 0.005 & 0.0002 \\
\hline Felid CSM & 0.018 & 0.0005 & 0.006 & 0.0001 & 0.029 & 0.0009 & 0.029 & 0.0009 & 0.038 & 0.0011 & 0.023 & 0.0007 \\
\hline N & \multicolumn{2}{|c|}{1200} & \multicolumn{2}{|c|}{1000} & \multicolumn{2}{|c|}{944} & \multicolumn{2}{|c|}{919} & \multicolumn{2}{|c|}{1113} & \multicolumn{2}{|c|}{960} \\
\hline
\end{tabular}

${ }^{1}$ abcd $=$ Cause-specific rates not sharing a letter within a column differ $(P<0.05)$.

comparison error rate by partitioning by the number of paired comparisons (Sokal and Rohlf 1981). We also used continuitycorrected binomial tests (Sokal and Rohlf 1981) to compare the proportion of cattle consumed by jaguars and pumas in the dry versus wet season against an even distribution.

\section{Jaguars and Puma Diets}

We collected jaguar and puma fecal samples in the period July 2000-April 2005, mostly from washes, trails, dirt roads, caves, ridges, and other movement routes. We identified species of scat by associated sign (tracks and scrapes) and occasionally by size, color, and shape (Aranda 2000; Rosas-Rosas et al. 2003). Scats were stored in paper bags and labeled with date, location, and associated sign.

We placed each scat sample in a plastic container and soaked samples in soapy water for $24-48 \mathrm{hr}$. We washed samples through three sieves of decreasing mesh size $(8.0,4.2,3.7 \mathrm{~mm})$ then dried in paper bags for $24 \mathrm{~h}$ under $100 \mathrm{~W}$ lights. Components of the samples including hairs, bones, teeth, feathers, scales, claws, hooves, and vegetation remains were stored in separate plastic bags. We used macroscopic characteristics of the sample remains to identify prey to order, family, genus, and species when possible. Tooth characteristics, claw type, size and shape of hooves, and macro- and microscopic characteristics of the hair (cuticular scales and medulla pattern) were used in identification (Rosas-Rosas et al. 2003). We used a reference mammal collection at New Mexico State University to identify or verify the identification of prey items.

We calculated frequency of occurrence (percentage of total scats in which an item was found), percentage of occurrence (number of times a specific item was found as percentage of all items found), and biomass of each prey species following Ackerman et al. (1984) and Nuñez et al. (2000). We used a randomization test (Efron and Tibshirani 1993) to test for differences in proportions of cattle and white-tailed deer consumed by jaguars and pumas by season, and for differences in cattle and white-tailed deer consumed by species within a season. We used only the predominant prey item per scat and generated $N=1000$ bootstrap iterations for paired comparisons.

\section{RESULTS}

\section{Calf Survival and Causes of Mortality}

A total of 919-1200 calves were produced each year, of which 20-124 were lost annually over the period 1999-2004 (Table 1). Calf survival averaged $0.933 \quad$ (SE $=0.017$; range $=0.889-0.980)$ over this period and did not differ among years $(Z \leq 0.18, P \geq 0.500)$. Most mortality was due to unknown causes $(n=240$; of these, $n=80$ were reported missing without any evidence of mortality in the area), jaguar predation ( $n=45$ confirmed; $n=9$ suspected), abandonment $(n=32)$, and abnormal parturition $(n=29)$. Pumas killed 12 calves, and an additional 19 were killed by coyotes.

Confirmed jaguar predation $(\leq 0.018)$, confirmed and suspected jaguar predation $(\leq 0.018)$, confirmed puma predation $(\leq 0.005)$, and all confirmed and suspected large felid predation $(\leq 0.018)$ rates were low annually (Table 2$)$. Jaguar predation on livestock was high relative to other causes of mortality during 1999 ( $Z>11.3, P<0.001)$, while unknownnonpredation causes were generally higher for 2000-2004 $(Z \geq 4.9$; $P \leq 0.001$; Table 2$)$.

If the 80 unknown-missing losses were included in large felid predation, annual predation rates increased to $0.006-0.038$ (Table 2), which would account for a maximum of $26-72 \%$ of annual calf mortality potentially attributable to large felid predation each year.

\section{Jaguar and Puma Predation}

We confirmed 45 jaguar and 12 puma kills of cattle, all calves $<12$ mo old over the period 1999-2004. The cause of an 
Table 3. Frequency $(F)$ of occurrence and percent relative biomass (B) of prey items consumed by jaguars and pumas seasonally and annually as determined by scat analysis, northeastern Sonora, Mexico, 1999-2004.

\begin{tabular}{|c|c|c|c|c|c|c|c|c|c|c|c|c|}
\hline \multirow[b]{3}{*}{ Prey } & \multicolumn{6}{|c|}{ Jaguar } & \multicolumn{6}{|c|}{ Puma } \\
\hline & \multicolumn{2}{|c|}{ Dry } & \multicolumn{2}{|c|}{ Wet } & \multicolumn{2}{|c|}{ Annual } & \multicolumn{2}{|c|}{ Dry } & \multicolumn{2}{|c|}{ Wet } & \multicolumn{2}{|c|}{ Annual } \\
\hline & $F(\%)$ & $\mathrm{B}(\%)$ & $F(\%)$ & $\mathrm{B}(\%)$ & $F(\%)$ & B $(\%)$ & $F(\%)$ & $\mathrm{B}(\%)$ & $F(\%)$ & B $(\%)$ & $F(\%)$ & B (\%) \\
\hline Cattle & 47.6 & 59.6 & 33.3 & 49.5 & 44.4 & 57.7 & 7.6 & 9.6 & 4.5 & 5.9 & 6.8 & 8.7 \\
\hline White-tailed deer & 28.6 & 25.9 & 16.7 & 17.9 & 25.9 & 24.3 & 47.0 & 57.3 & 45.5 & 57.6 & 46.6 & 57.3 \\
\hline Lagomorphs & 9.5 & 4.8 & 16.7 & 9.9 & 11.1 & 5.8 & 4.6 & 3.1 & 13.6 & 9.5 & 6.8 & 4.5 \\
\hline Collared peccary & 4.8 & 2.9 & 16.7 & 12.1 & 7.4 & 4.7 & 13.6 & 11.1 & 13.6 & 11.6 & 13.6 & 11.3 \\
\hline Coati & 4.8 & 2.5 & 16.7 & 10.5 & 7.4 & 4.1 & 9.1 & 6.5 & 4.5 & 3.3 & 8.0 & 5.7 \\
\hline Jaguar & 4.8 & 4.3 & 0 & 0 & 3.7 & 3.5 & 0 & 0 & 0 & 0 & 0 & 0 \\
\hline Raccoon & 0 & 0 & 0 & 0 & 0 & 0 & 6.1 & 4.4 & 4.5 & 3.3 & 5.7 & 4.1 \\
\hline Rodents & 0 & 0 & 0 & 0 & 0 & 0 & 4.5 & 2.9 & 0 & 0 & 3.4 & 2.2 \\
\hline Sonoran mud turtle & 0 & 0 & 0 & 0 & 0 & 0 & 1.5 & 1.0 & 4.5 & 3.0 & 2.3 & 1.5 \\
\hline Ring-tailed cat & 0 & 0 & 0 & 0 & 0 & 0 & 1.5 & 1.0 & 0 & 0 & 1.1 & 0.8 \\
\hline Opossum & 0 & 0 & 0 & 0 & 0 & 0 & 1.5 & 1.0 & 0 & 0 & 1.1 & 0.8 \\
\hline Long-tailed weasel & 0 & 0 & 0 & 0 & 0 & 0 & 1.5 & 1.0 & 0 & 0 & 1.1 & 0.8 \\
\hline Skunk & 0 & 0 & 0 & 0 & 0 & 0 & 1.5 & 1.0 & 0 & 0 & 1.1 & 0.8 \\
\hline Puma & 0 & 0 & 0 & 0 & 0 & 0 & 0 & 0 & 4.5 & 5.7 & 1.1 & 1.4 \\
\hline Unknown mammal & 0 & 0 & 0 & 0 & 0 & 0 & 0 & 0 & 4.5 & - & 1.1 & - \\
\hline N & 21 & - & 6 & - & 27 & - & 67 & - & 21 & - & 88 & - \\
\hline
\end{tabular}

additional nine predation events on calves was not confirmed; however, the predatory pattern suggested that those were also caused by jaguar, and these were classed as suspected jaguar predation (Table 2). Ninety-one percent (52/57) of jaguar and puma kills were found with associated tracks and/or scrapes; the rest were identified according to canine punctures in the braincase or the throat, or if there was some evidence of the carcass being buried. Most (binomial $P<0.001$ ) jaguar predation of cattle $(87 \% ; 39 / 45)$ occurred during the dry season. Puma predation also peaked during the dry season $(67 \% ; 8 / 12)$, but proportion of cattle killed did not differ between seasons (binomial $P=0.121$ ) for pumas.

Calves killed by jaguars averaged $91 \mathrm{~kg}$ in mass $(\mathrm{SD}=50)$ but ranged from $30 \mathrm{~kg}$ to $200 \mathrm{~kg}$. Three calves, aged $4 \mathrm{mo}$ $(60 \mathrm{~kg}), 5 \mathrm{mo}(130 \mathrm{~kg})$, and $7 \mathrm{mo}(140 \mathrm{~kg})$, survived jaguar attacks, but two of these died a few hours after the attack. Mean mass of calves killed by pumas was $53 \mathrm{~kg}(\mathrm{SD}=19$; range $=35$ $80)$. In two cases in which tracks of both pumas and jaguar were present at the kill site, the predatory pattern evidence in both cases indicated that the kill was made by a jaguar.

\section{Jaguar and Puma Diets}

We collected 27 jaguar and 88 puma scats from July 2000 to March 2005. Twenty-one jaguar fecal samples were collected during the dry season and six during the wet season. Sixty-six puma fecal samples were collected during the dry season and 22 during the wet season. Most $(96 \% ; 110 / 115)$ scats contained one prey item/scat, and 95\% (109/115) were associated with tracks and scrapes. We did not include scats collected from calf kill sites $(n=10)$ in scat analyses to avoid potentially biasing diets toward cattle.

Cattle accounted for $58 \%$ of the total biomass consumed by jaguars annually, followed by white-tailed deer $(24 \%$; Table 3). Conversely white-tailed deer accounted for $57 \%$ of the estimated biomass in puma diets annually, followed by collared peccaries $(11 \%)$ and cattle $(9 \%)$. Seasonally, biomass of cattle in jaguar $(P=0.082)$ and puma $(P=0.070)$ diets was marginally greater in the dry season. Because of the small sample size of scats collected during the wet season, we compared differences between jaguar and puma diets only for the dry season. In the dry season, jaguars consumed significantly more cattle $(P=0.009)$ than did pumas, but jaguars and pumas did not differ in consumption of white-tailed deer $(P=0.997)$.

\section{DISCUSSION}

Jaguars were the main predator of cattle in northeastern Sonora, although annual confirmed kill rates $(0-1.8 \%)$ were much lower than perceived by ranchers, who attributed all calf mortality to jaguar and puma predation. This was also true when all confirmed and suspected large felid predation was included (cause-specific mortality rates $\leq 1.8 \%$ ) and even when unknown-missing calves were included as felid predation (cause-specific annual rates $\leq 3.8 \%$; Table 2 ). Confirmed jaguar and puma predation totaled 57 of 408 total calf mortalities; this increased to 66 if suspected jaguar kills were included, and to 146 if unknown losses of missing calves were included in the total. Coyotes killed an additional 19 calves, making all predators potentially responsible for 40\% (165/408) of calf losses during our study; of this, jaguars were likely responsible for most (54-134). However, despite predation by both jaguars and pumas (and coyotes), calf survival was consistently high during our study $(\geq 0.89$; Table 2$)$ in northeastern Sonora, and calf crops were excellent in our study area $(89-98 \%$ for calves that reached parturition; Holechek et al. 2004), with the majority of calf losses due to factors other than predation (Table 2). For some small ranches, however, jaguar and puma predation may have been signifi- 
cant, as in cases where a jaguar constantly preyed on cattle on a single ranch. Comparatively, all confirmed and possible annual predation rates on calves were lower than observed in Brazil (0.047; Cascelli de Azevedo and Murray 2007).

Confirmed jaguar predation on cattle was usually associated with specific individuals or unique circumstances in our study area; $91 \%$ (41/45) of kills occurred in three localized cases. In 1999 there were 21 jaguar kills of cattle on a single ranch during the dry season in June. Tracks of two different jaguars, one about half the size of the other, were found, suggesting a female and her young (Rosas-Rosas 2006). After a month of cattle predation, two jaguars were observed near the last kill and one, a juvenile male approximately 5 mo old, was shot by a ranch worker. After this the predation ended, and no further predation was recorded in the area. This suggests that the problem was associated with a female jaguar and cub; possibly the female was teaching her cub to prey on cattle, or she fed on cattle because she needed the extra energy to feed her cub (Oftedal and Gittleman 1989). The other two cases of continuous localized jaguar predation on livestock occurred in 2001 and 2002-2003. In these cases 20 calves were killed, and, based on tracks and photographic identification (RosasRosas 2006), most were killed by two individual jaguars. After these individuals left the area, no other jaguar attacks on cattle were reported, despite the presence of four other jaguars in the area.

The predominance of cattle in jaguar diets $(58 \%$ of prey biomass consumed; Table 3), however, suggests that jaguar predation on cattle may be more continuous than the confirmed kills alone would suggest. Our study was the first case in which cattle were documented as a major prey item for jaguars in Mexico (Aranda and Sanchez-Cordero 1996; Nuñez et al. 2000), although cattle had been reported as a major prey item in several areas of Brazil (Dalponte 2002; Renata et al. 2002; Cascelli de Azevedo and Murray 2007). Jaguars are considered to be opportunistic predators (Emmons 1987) that rely mainly on medium and large-sized prey items $(\geq 10 \mathrm{~kg})$, which we saw in northeastern Sonora (Table 3). The average weight of cattle killed by jaguars was $91 \mathrm{~kg}$ (usually calves 14 mo old), which makes cattle a more profitable prey (Sunquist and Sunquist 1989) than white-tailed deer and other species that weigh less and require more energy to locate and catch. Therefore, some or all individual jaguars may learn to preferentially prey on cattle (Polisar et al. 2003), especially if alternative large prey is relatively rare, as was the case in our study area (Rosas-Rosas 2006). Consequently, total losses of calves to jaguar predation may be closer to confirmed and suspected kills plus some of the unknown-missing losses. Although some of these missing calves were likely killed by pumas, coyotes, or rustled, the predominance of jaguar kills in confirmed predation events and the high biomass of cattle in jaguar scats suggest that most were likely taken by jaguars.

Because multiple calf kills in a short time period or localized area were associated with individual problem jaguars in our study area, most problematic predation conflicts could potentially be managed by dealing with individual problem animals rather than broad-scale predator control. This is important given that ranchers routinely misidentified the predator responsible for kills in our study area; the association with specific problem individuals makes it crucial to correctly determine the species of predator. Because jaguars are endangered in Mexico (SEMARNAT 2002) and penalties for illegal killing can be severe, landowners would welcome alternatives to avoid killing the offending or wrong predatory felid. Jaguar predatory patterns have been carefully described in the Venezuelan Llanos (Hoogesteijn et al. 1993; Hoogesteijn 2001) and used to produce manuals for ranchers to identify the predator responsible for predation on livestock. There is no similar information available to distinguish between predators in Mexico, and development of such a tool could help minimize illegal killing of jaguars.

Last, most jaguar predation on cattle occurred during the dry season, usually in riparian habitats near permanent water sources (Rosas-Rosas 2006). During drought conditions, cattle ranchers move cattle to pastures adjacent to riparian corridors or pastures with permanent water sources to provide cattle with thermal cover, succulent forage, and water. These areas have rugged topography, dense surrounding vegetation, and permanent water sources, habitat characteristics that increase vulnerability to jaguar predation (Hoogesteijn et al. 1993; Cascelli de Azevedo and Murray 2007). These same habitat conditions also attract wildlife such as white-tailed deer, coatis, and peccaries, which increases the likelihood of presence of predators. Jaguars and to a certain extent pumas prefer areas with dense vegetation, which provides stalking cover for ambush predators like jaguars (Sunquist and Sunquist 1989). Similar situations exist with African lion (Panthera leo) predation on livestock; lions also use patches of dense cover to prey on livestock as well as frequent permanent water sources for hunting during dry seasons (Patterson et al. 2004). Alternative cattle management practices, such as providing permanent water sources in upland pastures to avoid concentrating cattle near dense riparian cover during the dry season, could minimize concurrent use of habitats by jaguars and cattle and thus decrease vulnerability to predation.

\section{MANAGEMENT IMPLICATIONS}

Jaguar predation on livestock in northeastern Sonora should be closely monitored, as reported predation losses differed greatly from actual and confirmed losses were generally associated with a few specific individual jaguars or locales. Identifying both predator species and individual is critically important for managing predation conflicts, as illegal killing due to livestock predation was the greatest cause of mortality for jaguars, an endangered species, in our study area. When jaguars prey on cattle, identification of factors that may be contributing to cattle vulnerability, such as problem areas or individual jaguars, needs to be accurately assessed. In northeastern Sonora, cattle management strategies that can help ameliorate livestock predation and illegal killing of jaguars potentially include fencing riparian areas where predation is common, creating alternative water sources away from riparian areas or areas with dense vegetative cover to distribute cattle during the dry season, and providing information on predatory patterns of jaguars and pumas to ranch workers and ranch owners to help correctly identify the predatory species. 


\section{ACKNOWLEDGMENTS}

We acknowledge the Mexican National Council of Science and Technology for providing a doctoral scholarship to O. C. Rosas-Rosas and the Jaguar Conservation Program of the Wildlife Conservation Society, US Geological Survey's New Mexico Cooperative Fish and Wildlife Research Unit, Summerlee Foundation, Secretary of Natural Resources of Mexico, New Mexico State University Agricultural Experiment Station, and the municipality of Nacori Chico, Sonora, for funding and other support provided for this project. In addition, we also acknowledge all the personnel, volunteers, tourists, cattle ranchers, and general public for their aid in field research activities.

\section{LITERATURE CITED}

Ackerman, B. B., F. G. Lindzey, and T. P. Hemker. 1984. Cougar food habits in southern Utah. Journal of Wildlife Management 48:147-155.

Aranda, M. 2000. Huellas y otros rastros de los mamíferos grandes y medianos de México. Veracruz, México: Comisión para el Conocimiento y Uso de la Biodiversidad, Instituto de Ecología, A. C. Xalapas. 212 p.

Aranda, M., and V. Sanchez-Cordero. 1996. Prey spectra of jaguar (Panthera onca) and puma (Puma concolor) in tropical forests of Mexico. Studies on Neotropical Fauna and Environment 31:65-67.

Brown, D. E. [ED.]. 1982. Biotic communities of the American southwest-United States and Mexico. Desert Plants 4:1-4.

Cascelli de Azevedo, F. C., and D. L. Murray. 2007. Evaluation of potential factors predisposing livestock to predation by jaguars. Journal of Wildlife Management 71:2379-2386.

Crawshaw, P. G., JR., and H. B. Quigley. 2002. Hábitos alimentarios del jaguar y el puma en el Pantanal, Brasil, con implicaciones para su manejo y conservación. In: R. A. Medellín, C. Equihua, C. L. B. Chetkiewicz, P. G. Crawshaw, Jr., A. Rabinowitz, K. H. Redford, J. G. Robinson, E. W. Sanderson, and A. B. Taber [EDS.]. El jaguar en el nuevo milenio. México, D.F., México: Universidad Nacional Autónoma de México, Wildlife Conservation Society, and Fondo de Cultura Económica. p. 223-235.

Dalponte, J. C. 2002. Dieta del jaguar y depredación de Ganado en el norte del Pantanal, Brasil. In: R. A. Medellín, C. Equihua, C. L. B. Chetkiewicz, P. G. Crawshaw, Jr., A. Rabinowitz, K. H. Redford, J. G. Robinson, E. W. Sanderson, and A. B. Taber [EDs.]. El jaguar en el nuevo milenio. México, D.F., México: Universidad Nacional Autónoma de México, Wildlife Conservation Society, and Fondo de Cultura Económica. p. 209-221.

EFron, B., And R. J. TibShirani. 1993. A introduction to the bootstrap. New York, NY, USA: Chapman \& Hall. 436 p.

Emmons, L. H. 1987. Comparative feeding ecology of felids in a neotropical rainforest. Behavioral Ecology and Sociobiology 20:271-283.

Heisey, D. M., AND T. K. Fuller. 1985. Evaluation of survival and cause-specific mortality rates using telemetry data. Journal of Wildlife Management 49:668-674

Holechek, J. L., R. D. Pieper, and C. H. Herbel. 2004. Range management: principals and practices. Upper Saddle River, NJ, USA: Pearson-Prentice Hall. 607 p.

HoogesteIJN, R. 2001. Manual on the problems of depredation caused by jaguars and pumas on cattle ranches. Workshop on survey protocols and method of standardization for research on jaguars. Tikal, Guatemala: Wildlife Conservation Society. $35 \mathrm{p}$.

Hoogestelun, R., E. O. Boede, and E. Mondolfi. 2002. Observaciones de la depredación de bovinos por jaguares en Venezuela y los programas gubernamentales de control. In: R. A. Medellín, C. Equihua, C. L. B. Chetkiewicz, P. G. Crawshaw, Jr., A. Rabinowitz, K. H. Redford,
J. G. Robinson, E. W. Sanderson, and A. B. Taber [EDS.]. El jaguar en el nuevo milenio. México, D.F., México: Universidad Nacional Autónoma de México, Wildlife Conservation Society, and Fondo de Cultura Económica. p. 183-197.

Hoogesteisn, R., A. HoogesteiJn, And E. Mondolfi. 1993. Jaguar predation and conservation: cattle mortality caused by felines on three ranches in the Venezuelan Llanos. Symposium of the Zoology Society London 65:391-407.

KitCHENER, A. 1991. The natural history of wildcats. New York, NY, USA: Comstock Publishing Associates. $280 \mathrm{p}$.

Marshall, J. T., JR. 1957. Birds of pine-oak woodland in southern Arizona and adjacent Mexico. Pacific Coast Avifauna 32:1-125.

Martínez-Caraza, L. 1983. El norte bárbaro de México. México, D. F., México: Editorial Panorama. $145 \mathrm{p}$.

Martínez-Mendoza, A. 2000. Jaguar occurrence in northeastern Sonora, Mexico [thesis]. Las Cruces, New Mexico, USA: New Mexico State University. 64 p.

Moreno-Martínez, J. F. 2004. La ganadería en el estado de Sonora, México: curso para la prevención y manejo de la depredación en ganado. Cojedes, Venezuela: Wildlife Conservation Society-MANFAUNA, Finca Matacalara. 17 p.

Nuñez, R., B. Miller, and F. Lindzey. 2000. Food habits of jaguars and pumas in Jalisco, Mexico. Journal of Zoology 252:373-379.

Oftedal, O. T., And J. L. Gittleman. 1989. Patterns of energy output during reproduction in carnivores. In: J. L. Gittleman [ED.]. Carnivore behavior, ecology and evolution, vol. 1. Ithaca, NY, USA: Cornell University Press. p. 355-378.

O'Gara, B. W. 1978. Differential characteristics of predator kills. Proceedings of the Biennial Pronghorn Antelope Workshop 8:380-393.

Patterson, B. D., S. M. Kasiki, E. Selempo, and R. W. Kays. 2004. Livestock predation by lions (Panthera leo) and other carnivores on ranches neighboring Tsavo National Park, Kenya. Biological Conservation 119:507-517.

Polisar, J., I. Maxit, D. Sconagmillo, L. Farrel, M. E. Sunquist, and J. F. Eisenberg. 2003. Jaguars, pumas, their prey base, and cattle ranching: ecological interpretations of a management problem. Biological Conservation 109: 297-310.

Pollock, K. H., S. R. Winterstein, C. M. Bunck, and P. D. Curtis. 1989. Survival analysis in telemetry studies: the staggered entry design. Journal of Wildlife Management 53:7-15.

Rabinowitz, A. R. 1986. Jaguar predation on domestic livestock in Belize. Wildlife Society Bulletin 14:170-174.

Renata, P., M. Leite, and F. Galvao. 2002. El jaguar, el puma y el hombre en tres áreas protegidas del Bosque Atlantico costero de Paraná, Brasil. In: R. A. Medellín, C. Equihua, C. L. B. Chetkiewicz, P. G. Crawshaw, Jr., A. Rabinowitz, K. H. Redford, J. G. Robinson, E. W. Sanderson, and A. B. Taber [EDS.]. El jaguar en el nuevo milenio. México, D.F., México: Universidad Nacional Autónoma de México, Wildlife Conservation Society, and Fondo de Cultura Económica. p. 237-251

Rosas-Rosas, 0. C. 2006. Ecological status and conservation of jaguars in northeastern Sonora, Mexico [dissertation]. Las Cruces, New Mexico, USA: New Mexico State University. 94 p.

Rosas-Rosas, O. C., R. Valdez, L. C. Bender, and D. Daniel. 2003. Food habits of pumas in northwestern Sonora, Mexico. Wildlife Society Bulletin 31:528-535.

[SEMARnAT] Secretary of Natural Resources of Mexico. 2002. Normas Oficiales Mexicanas (NOM-059-Ecol.) que determina las especies de flora y fauna silvestres terrestres y acuáticas en peligro de extinción, menazadas, raras y las sujetas a proteccion especial, que establece especificaciones para su protección. México, D. F., México. 153 p.

Sokal, R. R., and F. J. RohlF. 1981. Biometry. 2nd ed. San Francisco, CA, USA: W. H. Freeman. 859 p.

Sunquist, M. E., AND F. C. Sunquist. 1989. Ecological constraints on predation by large felids. In: J. L. Gittleman [ED.]. Carnivore behavior, ecology and evolution, vol. 1. Ithaca, NY, USA: Cornell University Press. p. 283-301. 